\title{
Rural Government Advisers in South Vietnam and the U.S. War Effort, | 962-| 973
}

\author{
$\because \quad$ Andrew J. Gawthorpe
}

\section{Introduction}

In the mid-1960s, as the U.S. effort to bring widespread change to the social, economic, and political fabric of rural South Vietnam was getting under way, a representative of the United States Official Mission (USOM) in that country stumbled across evidence of large-scale corruption among officials of the South Vietnamese government (known in U.S. terminology as Government of Vietnam, or GVN). The USOM official was stationed in the Mekong Delta, which crammed some 70 percent of the South Vietnamese population into 25 percent of its land area and was a key base of support for the Communist insurgents that made up the National Liberation Front (NLF). The official worried that the corruption he had uncovered "had implications all over the Delta," but he did not feel he had the authority to intervene directly in the GVN's affairs. Instead he made discreet inquiries to try to learn the facts and report them to his superiors in USOM. One night, after being invited by the local chief of police to take a ride to inspect a pro-government outpost, he felt a gun pressed against the back of his neck. The police chief, far from wanting to uproot corruption, wanted to intimidate the U.S. official and put an end to his questions. Afterward, the U.S. mission in Saigon took no action against the police chief and instead offered to transfer the badly shaken representative to another province. This episode was typical of U.S. attempts to transform a foreign society in which loyalties were opaque, power dynamics were never quite as they seemed, and individual U.S. reformers often found themselves alone. ${ }^{1}$

1. This story was related by one of the representative's superiors in Saigon. See Debrief No. 146612, pp. 9-10, in Box 99, Allan E. Goodman Papers (GP), Hoover Institution Archives (HIA), Stanford University. 
From the formation of an Office of Rural Affairs in 1962 until the final winding down of the U.S. presence in 1973, thousands of U.S. civilians traveled to the provinces and villages of South Vietnam. Acting as advisers to provincial and district governments throughout the country, they were supposed to strengthen these vital links between the GVN and the people of South Vietnam. From the time South Vietnam was formed in 1954, it had been a quintessential weak state. Unable to extract human resources and taxes from its own rural population, the GVN had been reliant on infusions of U.S. aid. The only way the South Vietnamese government could have overcome its reliance on what one historian has called its "American power source" was by developing administrative institutions that were both locally effective and responsive to the center. ${ }^{2}$ Working with—or sometimes against - their South Vietnamese counterparts, U.S. personnel were charged with imparting this type of government to the country.

To explore the U.S. nation-building project in South Vietnam from the perspective of the thousands of advisers who worked in it, this article introduces a new source base into the literature: a collection of official debriefings of rural advisory personnel found in the Allan E. Goodman Papers at Stanford University's Hoover Institution. ${ }^{3}$ The debriefings were conducted in Honolulu at the Asia Training Center of the U.S. Agency for International Development (USAID) and include not only USAID officials but also personnel from other civilian agencies and U.S. military advisers who were involved in the rural advisory effort in South Vietnam. Although the interviews do not provide exhaustive coverage of field advisory personnel, they cover all regions of South Vietnam and stretch from 1963 to 1973. The issues discussed here reflect viewpoints found across a broad section of the debriefings. When taken together with archival material from other sources-including additional oral histories, personal letters, and government documents from

2. Jeffrey J. Clarke, Advice and Support: The Final Years, 1965-1973 (Washington, DC: U.S. Center for Military History, 1998), p. 497.

3. Some of these interviews are also available in the National Archives II facility at College Park, Maryland. The extensive collection in the Goodman Papers has not, to my knowledge, previously been cited by researchers. Some 112 interviews, which have an average length of 22 pages, were reviewed in the preparation of this article. Because of a restriction imposed by Goodman's deed of gift to the Hoover Institution, which bans the identification of any person still living, the individuals whose words are being cited cannot in all cases be named, nor can precise details be given of when and where they served in South Vietnam. Instead, broader descriptions such as "a Province senior adviser who served in the Delta just after the Americanization of the war" are used. For extended discussions of individuals, pseudonyms such as "Mike" are assigned in addition to these descriptions. As printing the folder titles themselves would in some cases violate the deed of gift, interviews are instead cited by number and box, which is sufficient for any researcher to locate the cited material with ease. 
the Lyndon Baines Johnson Library and Museum, the Vietnam Center and Archive at Texas Tech University, and the U.S. National Archives-this collection provides an unparalleled look into the challenges of nation-building as viewed from the ground up.

The documents give new insight both into the nuances of U.S.Vietnamese relations in the nation-building program and into the way the United States attempted to generate on a crash basis the thousands of skilled personnel needed to carry out such a program. Dispatched to a foreign country of which they knew little, advisers struggled with a lack of linguistic ability and an incomplete understanding of the political, cultural, and social context within which they operated. Training programs designed to overcome these problems proved of dubious use. Even if advisers had possessed perfect information, they had limited ways to act on it. The regime they were charged with reforming often worked at cross-purposes with U.S. goals. Although the United States fielded hundreds of thousands of soldiers in South Vietnam and unleashed massive firepower on the country, this formidable military might was of little use in achieving reform on the part of a corrupt and inefficient South Vietnamese government.

This basic non-fungibility of military power meant that rural advisers could not achieve their goals by relying on the violence and coercion that one author has claimed was characteristic of the "real American war in Vietnam.." Instead, faced with the necessity of nation-building in South Vietnam and the uselessness of military force for this task, the United States tried to construct a network of rural advisers knowledgeable about South Vietnam and skilled in the arts of persuasion, cajolery, and manipulation.

The need to recruit, train, and deploy thousands of rural advisers as the war intensified — and to do so quickly-had ramifications both for the quality of advisers' preparation and the extent to which they worked according to a grand, unified plan. Historians of Cold War nation-building efforts have often focused on the efforts' ideological wellsprings, and students of the impact of modernization theory have examined thinkers and policymakers

4. Nick Turse, Kill Anything That Moves: The Real American War in Vietnam (New York: Picador, 2013). See also Bernd Greiner, War without Fronts: The USA in Vietnam (New Haven: Yale University Press, 2009). For critiques, see Gary Kulik and Peter Zinoman, "Misrepresenting Atrocities: Kill Anything That Moves and the Continuing Distortions of the War in Vietnam," Cross-Currents: East Asian History and Culture Review, No. 12 (September 2014), pp. 162-198; and the forum "U.S. Conduct in the Vietnam War: Commentaries on Bernd Greiner's War without Fronts," Journal of Cold War Studies, Vol. 13, No. 3 (Summer 2011), pp. 185-214, which includes critiques by Andrew J. Bacevich, Edwin Moïse, and Mark Atwood Lawrence plus a reply by Greiner. Greiner's reply prompted further critiques by Bacevich and Moïse in "Responses to Bernd Greiner on U.S. Conduct in Vietnam," Journal of Cold War Studies, Vol. 14, No. 1 (Winter 2012), pp. 111-113. 
in the metropole while recognizing that more work remains to be done on how U.S. nation-building programs actually operated on the ground. ${ }^{5}$ Responding to that call, this article argues that "high modernist" projects—such as President Lyndon Johnson's plan for a "TVA [Tennessee Valley Authority] on the Mekong"-were difficult to implement in the chaotic, confusing, and menacing environment that rural advisers confronted in Vietnam. ${ }^{6}$ Neither the GVN nor the U.S. personnel in South Vietnam were able to mobilize the power and resources for such sweeping transformations. Instead, when the nation-building effort is viewed from the perspective of the individual advisers, their defining experience was a lack of power-either the power to understand their environment or the power to change it. The same held true for the U.S. reform project in Vietnam writ large. Given these factors, the precise ideas and principles that underlay the design of U.S. reform efforts recede in importance because they could rarely be implemented as intended. $^{7}$

To relate the story of the U.S. rural advisory network in South Vietnam, the article proceeds in three sections. The first sketches the growth of the network aimed at solidifying the South Vietnamese regime by improving its ability to administer its rural population. This section demonstrates how the field advisory network grew from a small, jerry-rigged expedient into a vast bureaucracy consisting of specially trained personnel. The second section uses oral histories and archived training materials to examine the quality of the advisers' training and the impact it had on their ability to understand and influence rural South Vietnam. The final section then uses oral histories and a range of other archival materials to explore how effective U.S. personnel were at accomplishing this task once in the field. ${ }^{8}$

5. David Ekbladh, The Great American Mission: Modernization and the Construction of an American World Order (Princeton, NJ: Princeton University Press, 2010). See also Michael E. Latham, Modernization as Ideology: American Social Science and "Nation Building" in the Kennedy Era (Chapel Hill: University of North Carolina Press, 2000), pp. 8, 17; Daniel Immerwahr, "Modernization and Development in U.S. Foreign Relations," Passport: The Society for Historians of American Foreign Relations Review, Vol. 43, No. 2 (September 2012), pp. 22-26; and Edward Miller, Misalliance: Ngo Dinh Diem, the United States, and the Fate of South Vietnam (Cambridge, MA: Harvard University Press, 2013), ch. 1 .

6. On "high modernism," see James C. Scott, Seeing Like a State: How Certain Schemes to Improve the Human Condition Have Failed (New Haven: Yale University Press, 1998).

7. For considerations of these principles, see Patrick Lloyd Hatcher, The Suicide of an Elite: American Internationalists and Vietnam (Stanford, CA: Stanford University Press, 1990); and Jefferson P. Marquis, "The Other Warriors: American Social Science and Nation Building in Vietnam," Diplomatic History, Vol. 24, No. 1 (Winter 2000), pp. 79-105.

8. See my book To Build as Well as Destroy: The American Experience of Nation-Building in South Vietnam, 1965-73 (Ithaca, NY: Cornell University Press, f2018). 


\section{The Growth of the Field Advisory Network, 1963-1973}

U.S. personnel who worked as rural government advisers in South Vietnam were part of an effort that became larger, more militarized, more bureaucratized, and more urgent as U.S. involvement in the Vietnam War deepened. What started out in 1962 as a few dozen young men following the example of the Peace Corps and reading The Ugly American became by 1968 a force of thousands of older, more experienced, and more cynical civilian and military officials. What drove this transformation was the need for results in a nationbuilding effort intended to facilitate U.S. withdrawal from South Vietnam by fostering a self-sufficient GVN. The odd mixture of Peace Corps idealists and hard-nosed Cold Warriors who coexisted in the rural advisory network in South Vietnam at various times during its history makes for a fascinating case study relevant to the broader history of Cold War development initiatives.

Various U.S. agencies were active in South Vietnam before the Americanization of the war in 1965. These included the U.S. military under the Military Assistance Advisory Group (MAAG), the USAID officials whose mission made up USOM, State Department officers in the embassy, and Central Intelligence Agency (CIA) personnel. None of these agencies had an extensive presence in the provinces and villages of South Vietnam, and they rarely worked together to make the best use of their resources. Although USOM had deployed personnel to the provinces to help with the resettlement of refugees from North Vietnam in the 1950s, President Ngo Dinh Diem, ever sensitive to Vietnamese nationalism, had forced their withdrawal in 1958. ${ }^{9}$ Some U.S. officials in USOM also resisted the idea that their personnel should be deployed into the provinces to support local government, believing instead that USAID should run a "traditional" mission that focused on the GVN's central political and economic policymaking institutions in Saigon. They felt that the guerrilla crisis could best be handled by the military. ${ }^{10}$ The MAAG remained focused on preparing South Vietnam's armed forces (Army of the Republic of Vietnam, or ARVN) to fight a conventional war. Finally, although the CIA saw counterinsurgency warfare and the strengthening of GVN local

9. Asia Bureau, Office of Residual Indochina Affairs, Vietnam Desk, "Rural Development and Field Operations," in U.S. Agency for International Development, Terminal Report: United States Economic Assistance to South Vietnam, 1954-1975 (Washington, DC, 1975), pp. 4-5.

10. Ibid., p. 11; William A. Nighswonger, Rural Pacification in Vietnam: 1962-1965 (Washington, DC: ARPA, 1966), pp. 48-49; and George K. Tanham et al., War without Guns: American Civilians in Rural Vietnam (New York: Praeger, 1966), p. 30. 
governments as within its sphere of competence, the agency's efforts amounted to not even two dozen officers by late $1964 .{ }^{11}$

In 1962, the Kennedy administration gave impetus to a transformation of the USOM mission and the creation of the Office of Rural Affairs. That year, the administration dispatched former CIA officer Rufus Phillips to oversee the creation of a rural advisory effort. He soon requested that Albert $S$. Fraleigh, a USAID official, join him. Together, the two men, who had already worked on establishing a similar program in Laos, laid the foundations of what became the largest U.S. wartime nation-building effort in history. According to Fraleigh, the impetus for the expansion came in the aftermath of a visit to South Vietnam by the soon-to-be chairman of the Joint Chiefs of Staff (JCS) Maxwell Taylor and deputy National Security Adviser Walt Rostow in late 1961. Fraleigh remembered that the goal of the new effort was to "help the government of Vietnam decentralize and become more effective and responsive to the needs of its people." ${ }^{12}$

Phillips published a memoir of his experiences, but Fraleigh is less wellknown to historians despite playing as crucial a role in the early leadership of the Office of Rural Affairs. ${ }^{13}$ Born in Toronto, he was a naturalized U.S. citizen who described himself as a connoisseur of "rough and wild areas." During World War II he served with the U.S. Navy in the Pacific, working to persuade Okinawan civilians to refrain from committing suicide after the Battle of Saipan and instead to accept U.S. resettlement assistance. Shipwrecked on Okinawa by a typhoon in October 1945 and living in poverty on the beaches until he could be recovered, Fraleigh remembers being struck by the "sad conditions" of the Okinawans. He recalled: "I felt that we couldn't have these two very different standards of living - what we enjoyed and what the Asian peoples were forced to accept - and have world peace very long." Driven more by this concern over North-South relations than by the incipient Cold War, he went to work for the United Nations (UN) relief program in Shanghai in 1946, when China was embroiled in a civil war. In Shanghai, Fraleigh formed a friendship with Zhou Enlai, who later became foreign minister of the newly formed People's Republic of China (PRC). During the civil war, Zhou was responsible for collecting supplies from the UN relief mission to distribute in areas under Chinese Communist rule. Following the entry of Communist

11. Thomas L. Ahern, Jr., The CIA and Rural Pacification in South Vietnam (Washington, DC: Center for the Study of Intelligence, 2001), p. 133.

12. Debrief No. 3672 (Fraleigh), p. 3, in Box 98, GP, HIA.

13. Rufus Phillips, Why Vietnam Matters: An Eyewitness Account of Lessons Not Learned (Annapolis, MD: Naval Institute Press, 2008). 
forces into Shanghai in 1949, Fraleigh remained in the PRC for nearly two years and was harshly interrogated and subjected to Communist-mandated indoctrination sessions, which he later credited with honing his fluent Mandarin. After finally escaping the mainland through an appeal to Zhou, Fraleigh went to work with USAID in Taiwan in 1952 for nine-and-a-half years, during which time he met his Chinese wife. During a brief assignment in Laos, he met Phillips, and both worked to establish a field role for USAID in that country. When Phillips wanted to establish a similar program in South Vietnam, he summoned Fraleigh from Taiwan. ${ }^{14}$

Determined to overhaul what they saw as a hidebound and traditionalist mission, Fraleigh and Phillips recommended that USOM representatives be stationed permanently in the provinces of South Vietnam to advise province chiefs on local officials and to act as a conduit through which the local actors could request resources from the United States. Although Diem had previously been opposed to having U.S. representatives influencing local governments in the provinces, the deepening guerrilla crisis and his trust in Phillips eased his misgivings. ${ }^{15}$ For the United States, the aim of the program was not only to attempt to reform local organs of GVN power and make them more responsive to the people of South Vietnam but also to allow U.S. personnel to gather more information about what was happening in the South Vietnamese countryside. This goal was even more important after the overthrow of the Diem regime in November 1963, when it became obvious that U.S. officials had been misled by the GVN over the true state of affairs in the countryside. One Saigon-based official who arrived in mid-1964 remembered that all the United States knew about GVN performance at that point was "what the government of Vietnam knew that we wanted [to know]." This information gap made it impossible to know whether U.S. policy was helping to win the war and build a sustainable GVN. ${ }^{16}$

Phillips's and Fraleigh's efforts amounted to a revolution in the way USOM operated. When the pair arrived in Saigon, USOM had 120

14. Rufus Phillips et al., "Remembering Bert Fraleigh, 1920-2014," January 2014, Rural Affairs South Vietnam (unpublished, copy available from author); Debrief No. 3672 (Fraleigh), p. 1; and Bert Fraleigh, "The Story of America's Counterinsurgency Efforts in Vietnam in the Early 1960s," 1966, pp. 2-6, in Folder 30, Box 1, in Rufus Phillips Collection (RPC), Vietnam Center and Archive, Texas Tech University (VCA). (Fraleigh's memorandum is incorrectly labeled as having been published in 1966.)

15. Rufus C. Phillips III to Charles Stuart Kennedy, 19 July 1995, in Association for Diplomatic Studies and Training, Foreign Affairs Oral History Project, McLean, Virginia (ADST); and Debrief No. 3672 (Fraleigh), pp. 3-6.

16. Debrief No. 146612, p. 1. 
employees, but only three were stationed outside the capital. ${ }^{17}$ The two men set about recruiting a new breed of provincial representatives who would act as external eyes and ears in the provinces and give advice to province chiefs on matters of civil government. Unable to elicit volunteers from within USOM, Phillips and Fraleigh recruited a diverse bunch of experts from outside the agency. The group included former military officers, personnel from other U.S. agencies, and Peace Corps volunteers who had served in other countries. The first provincial representative was a former International Voluntary Services volunteer who was dispatched to Phu Yen, a province on the central coast, in September 1962. Another early recruit was David Hudson, a free-lance journalist who was willing to have a try at rural reform. Duly hired, he was dispatched to the southern tip of the delta, a redoubtable NLF stronghold. ${ }^{18}$ Some of the U.S. personnel in the program went on to storied careers in the executive branch, including Richard Holbrooke, John Negroponte, Hamilton Jordan, and Anthony Lake.

The eclectic background of recruits reflected the hostility that Fraleigh and Phillips felt toward the career USAID bureaucracy and their belief that amateur outsiders would be more pragmatic and energetic. This early group of young, idealistic representatives became known as "the Tigers" because of Fraleigh's stock motivational phrase, "You can do it, Tiger!"19 This phrase encapsulated Fraleigh's belief that energetic youngsters would outperform more experienced bureaucrats. He explicitly modeled what he wanted in a recruit on the young "BA generalists" favored by the Peace Corps, which Fraleigh later claimed to have had a hand in founding. ${ }^{20}$ Although some of the recruits had specific technical skills, especially in agriculture, most did not. As in the Peace Corps, Fraleigh and Phillips did not believe that representatives should go into the field with rigid and formulaic instructions; rather, they should listen to the problems of their local government counterparts and take a pragmatic approach to helping them. Fraleigh would later approvingly remember the "Peace Corps type of feeling" among his early recruits. ${ }^{21}$

If what Fraleigh sought in the Tigers were young men animated by the ideals of the Peace Corps and possessing a globetrotting spirit and cultural

17. Debrief No. 3672 (Fraleigh), p. 3.

18. Ibid., p. 8; and Phillips, Why Vietnam Matters, p. 130.

19. Debrief No. 3672 (Fraleigh), p. 25.

20. Fraleigh claimed that he was involved in convincing Congressman Clement Zablocki (D-Wisconsin) of the value of the Peace Corps and that Zablocki then sold the concept to President John F. Kennedy. See Fraleigh, "The Story of America's Counterinsurgency Efforts," p. 12.

21. Debrief No. 3672 (Fraleigh), p. 10. 
curiosity similar to his own, he openly disdained the unadventurous and even downright cowardly attitude that he believed was typical of career USAID employees in South Vietnam. In 1966 he wrote in a letter to a friend: "Among so many of our civilians there is apathy, unwillingness to accept a hard life and hard conditions or to make prompt decisions. Yet, a few miles away, less lucky American men die in battle." 22 Fraleigh compared the USOM employees' luxurious living conditions, lack of local understanding, and "big lunches" to the eponymous "ugly Americans" of Eugene Burdick and William Lederer's novel. ${ }^{23}$ By contrast, the Tigers received only a small per diem, could go months without seeing another Westerner, and were often exposed to danger. Unlike later generations of U.S. personnel in South Vietnam, they lived off the local economy rather than relying on lavish logistical support. If the career bureaucrats were the "ugly Americans," the Tigers were supposed to be real-life incarnations of Homer Atkins, the hero of the Burdick-Lederer book who lived plainly among the local people, not presuming to impose some set program of change and instead listening to their problems and helping solve them with adapted know-how.

To the dismay of Fraleigh and Phillips, the "ugly Americans" did not take this attempt to revolutionize USOM lightly. In the summer of 1964, career USAID official James "Big Jim" Killen was appointed head of the mission. Killen questioned whether the provincial agents tended to sap the autonomy of GVN local government by "institutionalizing an excessive dependence on the USOM representative to do things they should be doing for themselves?" Apparently believing the answer to be yes, he accordingly took steps to reduce the importance and influence of USOM representatives by removing their ability to control the release of funds and commodities to provincial governments, which had formerly been used as a means of influence over their GVN counterparts. ${ }^{24}$ Killen was a traditionalist who was averse to the Peace Corps spirit of the Office of Rural Affairs and had little faith in young college generalists. He also believed that U.S. citizens should maintain a distance from the Vietnamese, and he even launched security investigations against some of the Tigers on the spurious grounds that they had homosexual relationships

22. Fraleigh quoted in Francis Wheat to Johnson, 7 July 1966, in Box 221, Subject File, Ex ND 19/CO 312, White House Central Files (WHCF), Lyndon Baines Johnson Presidential Library (LBJL), Austin, TX.

23. William J. Lederer and Eugene Burdick, The Ugly American (New York: W. W. Norton, 1958). For Fraleigh's comments, see Fraleigh, "The Story of America’s Counterinsurgency Efforts," p. 17; and Debrief No. 3672 (Fraleigh), p. 10.

24. Nighswonger, Pacification, pp. 48-49; and Tanham, War without Guns, p. 30. 
with the Vietnamese with whom they lived and worked in the provinces. ${ }^{25}$ At the same time, Killen took aim at the principle of giving provincial representatives a per diem to live off the local economy and insisted that they be provided with a higher standard of living as a means of inducing respect from the Vietnamese.

In late 1964, Killen had Fraleigh recalled to Washington and ejected more than 30 of the Tigers, believing they should be replaced by older and more experienced advisers from within USAID. Fraleigh launched a bitter attack on Killen in interviews conducted as part of his debriefing, arguing that Killen's tenure marked the bureaucratization of the Office of Rural Affairs and a departure from the idealism and adaptability he believed were necessary for the success of the program. ${ }^{26}$ Fraleigh eventually resigned from USAID altogether in 1967, disgusted by what he viewed as the gutting of the program he had helped establish. Back in Washington, one Tiger wrote a ballad titled "The Legend of James D. Killen" to lament the changes. "The moral of the story, is plain with A-I-D," it read, "You don't work for the people, you work for bureaucracy!" 27

Alongside these disagreements within USAID were the inevitable tensions between any program based on the idealistic and non-prescriptive approach of the Peace Corps and The Ugly American and the grim necessity that drove a nation-building effort in a war zone. Secretary of State Dean Rusk had argued that the Peace Corps could not be viewed as "an instrument of foreign policy," because to do so would rob it of its usefulness "to foreign policy." 28 Instead, the value of the Peace Corps supposedly lay in the image of thousands of idealistic young Americans toiling selflessly for the benefit of others rather than for themselves or their own country. The process itself was more important than any concrete results. ${ }^{29}$ The Peace Corps did not have a presence in South Vietnam precisely because of a desire to maintain the distinction pointed out by Rusk. However, the ranks of the Tigers included former Peace Corps volunteers who were ready to work more directly for the

25. Fraleigh, "The Story of America's Counterinsurgency Efforts," p. 28.

26. Fraleigh's most personal criticisms were not included in the final printed report published after his debriefing. For the original comments, see Bert Fraleigh, interview, 3 February 1967, pp. 27-33, in Folder 16, Box 2, RPC, VCA.

27. "Paper and Song Lyrics-The Greatest Years of The Pig: 1962-1964 in the Rural Areas of South Vietnam," n.d., in Folder 30, Box 1, RPC, VCA.

28. Quoted in Elizabeth Cobbs Hoffman, All You Need Is Love: The Peace Corps and the Spirit of the 1960s (Cambridge, MA: Harvard University Press, 2000), p. 99.

29. Ibid., ch. 5; and Fritz Fischer, Making Them Like Us: Peace Corps Volunteers in the 1960s (Washington, DC: Smithsonian Institution Press, 1998). 
benefit of U.S. foreign policy aims. Some, as Fraleigh remembered approvingly, even hitchhiked their way to the country to sign up. ${ }^{30}$ But as the situation in South Vietnam deteriorated in the run-up to the Americanization of the war in 1965, many U.S. officials in South Vietnam began to question whether the attitude that these hitchhiking Tigers brought with them was commensurate to the task at hand. The core of their critique was that the rural advisory effort, which was so crucial for U.S. objectives in the war, was indisputably an instrument of U.S. foreign policy and hence could not operate the way the Peace Corps did. Most of all, it had to show results.

As the stakes in South Vietnam grew higher, the Peace Corps mantra that there was no one better for an undefined task than an undefined person seemed less and less convincing as a way to deliver results. ${ }^{31}$ The growth in the size and importance of the rural advisory effort attracted the attention of other government agencies, causing many to question whether "BA generalists" in their 20s from the Peace Corps or IVS could effectively advise South Vietnamese province chiefs. In the mid-1960s almost all province chiefs were field-grade officers with decades of experience fighting the war and surviving the byzantine politics of the ARVN. "[Y] ou couldn't get a province chief to listen to a boy of 22 or 23," said one USOM official who served in South Vietnam in 1966, summing up a common perspective. "He knew he wouldn't have the experience." 32 Tran Ngoc Chau, the chief of Kien Hoa Province, remembered that his reaction to seeing the freckled young American who was supposed to serve as his adviser was to think, "I don't need any babies down in this province; I've got enough problems." ${ }^{33}$ Long-serving agricultural experts in USOM agreed that young generalists without a technical or vocational background had little to offer. ${ }^{34}$ Although Fraleigh thought younger personnel were less rigid in their thinking and more open to foreign cultures, others detected a youthful arrogance. Some U.S. critics felt that the Tigers' zeal did not make up for their deficiency in maturity and cultural sensitivity, meaning they did not have "enough patience to find out what the situation is before they have all the answers." 35 One adviser even wrote a ditty mocking

30. Debrief No. 3672 (Fraleigh), p. 10.

31. On this point, see Fischer, Making Them Like Us, p. 139.

32. Debrief No. 21666, p. 10, in Box 100, GP, HIA.

33. Quoted in Phillips, Why Vietnam Matters, p. 133.

34. Debrief No. 3672 (Fraleigh), p. 16; and Rutherford Poats and John Bennett, interviewed by Charles Stuart Kennedy, 2 February 1990, in ADST.

35. Debrief No. 3681, p. 2, in Box 97, GP, HIA. 
the pretensions of his youthful colleagues. "Now Colonel, you're forty, I'm just twenty-two," it began, "but I've been to college, so I'll advise you"! 36

Killen's belief that the Office of Rural Affairs should not apply pressure on South Vietnamese local governments to force them to reform was also contrary to the general trend of U.S. activity in South Vietnam. His tenure coincided with the Americanization of the war in 1965, which ultimately transformed the rural advisory effort. Not only did the influx of U.S. troops and assets from 1965 onward provide an as-yet-undreamed-of level of potential resources to direct toward aiding South Vietnamese local governments, it also dramatically raised the stakes in the conflict. Simply hoping that the GVN would start acting properly was no longer sufficient when U.S. soldiers were dying to protect the Saigon regime. Furthermore, the eventual withdrawal of these soldiers presupposed that the GVN would attain the effectiveness and autonomy needed to stand up to the Vietnamese Communists on its own. This in turn was necessary for the United States to declare victory in a war in which its own credibility was now at stake. "If we lose in Vietnam," the authors of an influential U.S. Army report commented, "we pay the price no matter how carefully American officials rationalize the need to respect Vietnamese sovereignty." ${ }^{\text {' }}$

The strategic need to strengthen the GVN prompted a series of reorganizations of the rural advisory effort by the Johnson administration. ${ }^{38}$ The first step was the formation of the Office of Civil Operations (OCO) in late 1966, which created a much larger U.S. presence in each locality. Under this new setup, about half a dozen civilians served under a province representative. The few Tigers left in the country found themselves no longer qualified for such a senior position, and those who were not forced to leave became assistants and deputies to the new breed of representatives. ${ }^{39}$ Where the Tigers remained, they were submerged into larger organizations. The new province representatives typically were experienced USAID employees, Foreign Service Officers (FSOs) with decades of experience, or senior ex-military personnel.

36. CFAA newsletter No. 10, July 1972, p. 1, in Folder "CFAA Newsletters, 1971-72," Box 45, HQ MACV, Office of Civil Operations and Revolutionary Development Support, Plans, Programs and Policies Division, CORDS Historical Working Group Files (hereinafter referred to as CORDS History Files), Record Group (RG) 472, National Archives II at College Park, Maryland (NARA).

37. U.S. Department of the Army, A Program for the Pacification and Long-term Development of South Vietnam, Vol. 1 (1966), p. 55.

38. The developments in Washington that underlay these reorganizations are beyond the scope of this article, which focuses on the views and experiences of personnel in South Vietnam itself. For a bureaucratic history, see Thomas W. Scoville, Reorganizing for Pacification Support (Washington, DC: Center of Military History, 1982).

39. Debrief No. 21666, p. 10. 
Still unhappy with the rural advisory effort, the Johnson administration took the dramatic move in May 1967 of placing it under the auspices of the military with the creation of the Office of Civil Operations and Revolutionary Development Support (CORDS). Although OCO was still headed by a civilian, roughly half of the field personnel in the rural advisory network were drawn from the military from this point onward. The transfer of jurisdiction to the military had become inevitable given the vast quantity of U.S. military personnel and resources pouring into South Vietnam from 1965 on, compared to the relatively paltry contributions of the civilian agencies. It also represented an attempt by the Johnson administration to kick-start the program and enhance its ability to influence local governments in South Vietnam. Henceforth, the chief adviser in each province was known not as a provincial representative but as a province senior adviser (PSA), and each district of the province likewise had a district senior adviser (DSA). At the time CORDS was created, roughly half of PSAs and nearly all DSAs were drawn from the military.

The new titles of the organizations and postings reflected a new focus on advising and influencing the GVN at all levels. CORDS personnel lacked the freewheeling autonomy of the Tigers, but they were united into one organization that could apply pressure up and down the GVN hierarchy. Many advisers believed this was the only way to achieve results. "The guy that's operating as a representative of the United States government to the senior representative of the Vietnamese government," commented one USAID official who served in 1967, "packs a lot more weight with his suggestions than some guy who identifies himself with the Peace Corps." ${ }^{40}$ Under CORDS, U.S. provincial organizations were about 30 to 70 individuals strong, and the district teams subordinate to them were about eight strong. The PSA was in charge of a large organization that included U.S. personnel, local Vietnamese, and third-country nationals.

Although historians have tended to regard CORDS as an all-American organization, it in fact by 1970 employed more Vietnamese and third-country nationals than it did Americans. ${ }^{41}$ Many of the non-Americans worked in administrative support roles, but two elite groups of them worked for CORDS. The first were English-speaking Filipinos who were hired by USAID as community development officers (CDOs). The Filipinos served longer tours than their U.S. counterparts, and some advisers saw them as providing vital continuity and community development expertise that they had gained working in

40. Debrief No. 14676, p. 3, in Box 94, GP, HIA.

41. "Opening Statement by Ambassador W. E. Colby," n.d., p. 12, in Folder "Opening statements/Amb. Colby," Box 15, CORDS History Files, RG 472, NARA. 
their own country. ${ }^{42}$ The Tigers had begun to employ CDOs in 1964, and by the late 1960s many of them had been in the country for four or five years. By May 1969, 106 CDOs were working in South Vietnam, averaging more than two per province. ${ }^{43}$ "It was what I really wanted to get into when I got over there," remembered one U.S. adviser who arrived in 1967, "but I found that the Filipinos really have it sewed up. You just about have to be a Filipino to get the job." ${ }^{44}$ While keeping would-be U.S. community workers out of a job, the CDOs had linguistic and cultural skills that were highly prized by the PSAs for whom they worked. "Area specialists," another holdover from the Tigers, constituted the second important group of non-Americans working for CORDS. PSAs employed these locally hired Vietnamese as translators, guides, and fixers, as well as executive agents who could be sent to pressure lower-level GVN officials and integrate into Vietnamese rural life in a way that Americans could not.

CORDS existed from 1967 to 1973, reaching peak size from 1969 to 1971. As the United States began to withdraw from South Vietnam under President Richard Nixon and the policy of Vietnamization proceeded, the organization shrank rapidly in 1971, undermining its influence. At the same time, its work became all the more important as the GVN nervously looked ahead to the day when it would have to stand up to the Vietnamese Communists without the aid of U.S. resources. In contrast to the small Office of Rural Affairs started by Fraleigh and Phillips, CORDS was a bureaucratic behemoth with formal performance reviews and quantifiable targets measuring advisers' success in persuading their GVN counterparts to do such things as recruit local militias, carry out development projects, and hold village elections. Rather than one or two U.S. advisers per province, under CORDS there could be hundreds. This constituted a dramatic shift from the freewheeling, Peace Corps-inspired early days of the rural advisory effort. Although the strategic importance of the nation-building effort in South Vietnam and the attention it attracted from other government agencies made this development inevitable, it also raised the question of whether the United States could train and deploy thousands of personnel with the sophisticated understanding of South Vietnamese society and governance needed to work closely with their GVN counterparts to improve rural governance throughout the country.

42. Debrief No. 26683B, pp. 20-21, in Box 98, GP, HIA.

43. Memorandum, James Zumbrunnen to Lee Braddock, 5 May 1969, in Folder "Effect of the inf co intens. pacif program/Goals 1970 P+D plan," Box 9, CORDS History Files, RG 472, NARA.

44. Debrief No. 18694, p. 10, in Box 99, GP, HIA. 


\section{"You Don't Know What on Earth You're Going to Do": The Limits of Preparation}

Intimate involvement in the affairs of distant countries was a key feature of the Cold War experience for the United States, but in South Vietnam this involvement arguably went further than anywhere else. Thousands of U.S. advisers served in CORDS during its existence, charged with analyzing the society, economics, and politics of South Vietnam and persuading their GVN counterparts to carry out reforms that would strengthen the country's ability to stand alone against the Vietnamese Communists. How to generate the skilled personnel to carry out this charge became a key question for the U.S. nation-building effort.

Before the advent of CORDS, training programs for rural advisers were limited or non-existent, partly because many of the Tigers had already worked in Vietnam and had local knowledge and linguistic abilities. The fact that Fraleigh and Phillips had to rely on finding such talented and knowledgeable recruits without the ability to generate them through training had limited the scale of the program. It also sometimes meant sending recruits into the field unprepared when needs were urgent, as one of the advisers discovered when he was dispatched to the crucial province of Kien Hoa with only one hour of language training. ${ }^{45}$ Fraleigh and Phillips sent the Tigers into the countryside with a broad remit to improve the social, economic, and political life of the rural population by making local institutions more effective and responsive to popular needs, but without extensive formal training. ${ }^{46}$ CORDS's vast personnel requirements called for a different approach.

The creation of CORDS meant that the United States needed to generate, on a crash basis, thousands of personnel who had the requisite skills, sensitivity, and patience to be rural government advisers. Although many existing government employees from the military, USAID, and State Department were slotted into CORDS, an extensive recruitment drive was also launched. In the twelve-month period ending October 1966, the agency responded to 27,000 inquiries regarding service in Vietnam and ultimately hired 544 people. ${ }^{47}$ In April 1967, a cross-agency Vietnam Training Center (VTC) was inaugurated in Washington to formalize and increase the quality of training. Some 2,000

45. Debrief No. 16612, p. 1, in Box 98, GP, HIA.

46. Bert Fraleigh, interview, 3 February 1967, p. 34.

47. Attachment to memorandum, William Gaud to Marvin Watson, 6 October 1966, in Box 120, Subject File, Ex FG 105-4, WHCF, LBJL. 
U.S. citizens passed through the VTC during its existence. ${ }^{48}$ As part of the Foreign Service Institute, the VTC provided courses up to ten months long in which future PSAs and DSAs took classes in Vietnamese language, history, and culture; the theory and practice of countering revolutionary war; and their own roles within CORDS.

Course attendees read texts and attended lectures by such luminaries as the British counterinsurgency expert Sir Robert Thompson and former field personnel such as Fraleigh. ${ }^{49}$ In theory, trainees were also able to read the latest provincial reports and speak to CORDS advisers who had previously worked in the areas to which they were to be assigned. However, they often did not know what area this would be until they arrived in South Vietnam, which made the utility of a central training program dubious. One of the most challenging tasks for any new adviser was getting to know the specific social, economic, and political factors that were important in the province in which he served. "I believe it is a basic mistake to regard Vietnam as an homogenous area for which detailed directives and procedures can be established at central level and stipulated to be applicable throughout," James Megellas, leader of CORDS in II Corps, remarked in 1970. "Even within any specific CTZ [Corps Tactical Zone] the individual provinces have enough differences to preclude this type of direction being feasible at regional level, much less on a country-wide basis." ${ }^{50}$ If the new advisers were lucky, they might overlap with their predecessors long enough to pick up information from them on the local situation, but this was not always the case. Given the social and economic differences between provinces, the quality of the local government institutions, and the disposition of the local NLF units, advisers faced a steep learning curve. Yet during their training, they often had no idea whether they were going to be deployed to an almost entirely peaceful province like An Giang or a battlefield area near the demilitarized zone.

Reactions to the course were mixed. Language training was a large part of it, but only a few advisers were able to engage in more than small talk when they arrived in South Vietnam. Although many province chiefs spoke English or French, advisers without facility in the Vietnamese language were unable to speak with the ordinary villagers whom they were supposedly in the province

48. Fraleigh, "The Story of America's Counterinsurgency Efforts," p. 34.

49. Debrief No. 6683, p. 2, in Box 97, GP, HIA; and Vietnam Area Studies OCO Training Center, n.d., in Folder 12, Box 09, John Donnell Collection, VCA.

50. Memorandum by James Megellas to Creighton Abrams, 19 May 1970, p. 36, in Folder "End of tour /J. Megellas," Box 23, CORDS History Files, RG 472, NARA. 
to help. ${ }^{51}$ Nor was the language training always in the appropriate dialect. "Johnny" described his "shock" upon arriving in Quang Tri Province in 1965 and discovering that the locals spoke "such a rude rural central dialect." A regionalist rebellion against Saigon that broke out in the province in early 1966 could only have heightened his discomfort at speaking the dialect of the capital. ${ }^{52}$ Even the legendary former U.S. Army officer John Paul Vann requested a leave of absence to develop his poor Vietnamese language skills in 1971 — and had his request denied..$^{33}$

In the view of "Brad," a USAID official who was assigned to the staff of a GVN agency in 1966 and hence saw the relationship from the other side, the poor standard of English spoken by GVN officials often caused the U.S. advisers to view them as intellectually inferior. ${ }^{54}$ One Saigon-based adviser who traveled to many provinces as a program auditor reported being "terrifically" impressed in the mid-1960s that "you could go to practically any province and you found people who spoke English.” Although urbane GVN officials like Nguyen Duc Thang, a high-ranking favorite of the United States, were accorded respect for their linguistic skills, the many Vietnamese who could not match them were looked down upon. ${ }^{55}$ Thomas Barnes, the head of CORDS in the populous Mekong Delta in 1971, even issued a directive banning advisers from speaking in "baby talk" to their counterparts because it demeaned the relationship. ${ }^{56}$ Because more highly educated GVN officials from urban backgrounds-including many who had received education or military training in the United States-were easier for U.S. personnel to talk to, the range of Vietnamese perspectives they heard was inevitably limited by poor linguistic skills.

Some U.S. recruits found the part of the training course dealing with revolutionary warfare to be revelatory. A rural development adviser who attended the course in 1967 remembered it as his first introduction to the idea that insurgencies had political causes and needed political solutions. Despite

51. Debrief No. 86711, pp. 1-2, in Box 99, GP, HIA; Debrief No. 30663, p. 7, in Box 99, GP, HIA; and Debrief No. 25672, pp. 14-15, in Box 99, GP, HIA.

52. Debrief No. 206612, p. 1, in Box 101, GP, HIA.

53. Memorandum by George Jacobson to William Colby, 29 January 1971, in Folder "Mr Jacobson / Misc files/A C of S/Folder III," Box 36, CORDS History Files, RG 472, NARA.

54. Debrief No. 23666, pp. 1-2, in Box 94, GP, HIA.

55. Debrief No. 21666, pp. 20-22. On Nguyen Duc Thang's relationship with U.S. personnel, see James McAllister, "What Can One Man Do? Nguyen Duc Thang and the Limits of Reform in South Vietnam,” Journal of Vietnamese Studies, Vol. 4, No. 2 (Summer 2009), pp. 117-153.

56. Message, Thomas J. Barnes to all PSAs, 7 October 1971, p. 2, in Folder “Barnes, Thomas J.,” Box 25, Sheehan Papers, U.S. Library of Congress. 
his recent introduction to the topic, he felt that "if a person took any interest in the course at all that it became clearto [sic] him fairly soon what causes an insurgency and how you must deal with it." ${ }^{57}$ But most found, upon arriving in their assigned province, the situation to be hugely discombobulating and soon had a more modest view of their capabilities. One PSA who served on the central coast in 1968 found that he had not really been able to imagine the reality of "what you're going to be doing in Asia" from the comfort of a classroom..$^{58}$ An assistant province adviser who had received six months of training, including five months working on the language, remembered,

When you first get out to a province you are bewildered, you don't know what on earth you're going to do. You really haven't been told, except in a general sort of way, exactly what it is you're supposed to do. ${ }^{59}$

Some advisers complained of more quotidian experiences of culture shock of the sort that U.S. travelers abroad have long voiced. "Felix," a naturalized Filipino-American, found he could not distinguish between the various provinces of South Vietnam upon arrival "since they all seemed to have similar names." He also complained about encounters with "shoeshine boys" who obliged him to pay them whether he wanted their service or not. ${ }^{60}$ Although "Felix" felt that his previous experience of living in the Philippines had helped cushion him from the culture shock of arriving in South Vietnam, most U.S. recruits had not had similar preparation.

Many of the Tigers had worked in South Vietnam for years and gained an understanding of Vietnamese language, culture, and history. The post-1965 advisory network instead operated on the principle that older individuals with no experience of Vietnam could be taught these things and then sent into the field to become agents of change in the rural South. "Johnny," the adviser who discovered he spoke the wrong dialect only upon arriving in Quang Tri, replaced a Tiger who had been in the province for three-and-a-half years. ${ }^{61}$ Fraleigh had believed that young minds were the most adaptable to new cultures and less prone to be prescriptive and rigid in their view of what was to be done to aid local governments. By contrast, many of the VTC inductees were already experienced professionals whose worldviews were more difficult to mold in just several months of training. For instance, although experts in

57. Debrief No. 18694, p. 10.

58. Debrief No. 16683, p. 3, in Box 99, GP, HIA.

59. Debrief No. 6683, p. 7.

60. Debrief No. 26683B, pp. 2, 12.

61. Debrief No. 206612, p. 1. 
"cross-cultural communication" were retained as instructors, many course attendees reportedly believed they had little to be taught in this area. ${ }^{62}$ "Earl," who arrived in Vietnam in the aftermath of the Tet Offensive, recalled the following incident:

We had somebody from the Justice Department who got up and started crying about militant black power; about the Negro who had been abused; about a poor woman down in Alabama who was merely taking her clothes home to wash them after hours from the laundry and [was] accused of stealing. I could see right through their scheme. It was to make somebody who was a segregationist blow up and make a scene in the classroom. It did make you boil to sit there and hear that crap. ${ }^{63}$

Although the training program made an effort to filter out those with racist views, "Earl's" experience shows how difficult this was.

Given the vastly increased personnel requirements of CORDS, it was impossible to produce advisers with homogenous views on the scale required. Combined with the fact that many rural advisers did not attend a training course at all because the need for immediate deployment of personnel in Vietnam was so great, the result was a wide diversity of views among the advisers about what their job entailed and how best to accomplish it. To understand how the U.S. nation-building project in South Vietnam actually operated, we must take account not only of contemporary ideological tendencies such as modernization theory but also the sheer multiplicity of worldviews, experiences, and temperaments that inevitably existed among such a large number of people. ${ }^{64}$

\section{Understanding and Influencing Rural South Vietnam}

The need to train and deploy thousands of rural government advisers on a crash basis means that the thousands of recruits who went to fill the ranks of CORDS defy easy generalization. How advisers conceptualized their roles depended on their own predilections and backgrounds. Some saw themselves

62. Evaluation of the Province Senior Advisor Training Program, n.d., p. 1, in Folder "PER Vietnam Training Center, 1970," Box 8, Subject Files of the Office of Vietnam Affairs (Vietnam Working Group), 1964-74, RG 59, NARA.

63. Debrief No. 4696, p. 2, in Box 98, GP, HIA.

64. Ekbladh, Great American Mission, p. 11. 
as engaged in "missionary" work. As one PSA with a background in both the U.S. Air Force and USAID explained, this mission involved spreading educational and social benefits to less-fortunate peoples. This seemed to occasion some pride. "You are unique," he explained, "you are going to accept the responsibilities of the job of helping other people without giving a great deal of thought to your own personal safety." 65 This focus on "helping people" allowed the advisers to differentiate their role from that of the majority of gun-wielding U.S. soldiers in South Vietnam. "This is why Americans are in Vietnam," said one U.S. adviser who was stationed in Dinh Tuong Province in 1967-1968.

They're not there to fight the war-they're there to work with the Vietnamese civilians and try to help them on as personal a basis as can be established. The little bit that our civilians can accomplish is really worthwhile. They can show the Vietnamese that the Americans aren't the big bad guys that the soldiers in the field seem to be. We're not just out there killing innocent women and children. Sure this happens many times; it's unavoidable in war. But our civilians can show the Vietnamese that that's not our mission. ${ }^{66}$

Although some advisers carried weapons for self-defense, especially in highly insecure areas such as Quang Tri Province, others felt that carrying weapons would cause villagers to associate them with the military and view them less positively. ${ }^{67}$

Some advisers conceived of their goal as bringing the benefits of social, economic, and political development to the less fortunate, and their views fit broadly within the mainstream of modernization discourse. Others were dismissive and even contemptuous of this point of view. Some advisers were clear that their role was not primarily to help the people of South Vietnam but to strengthen its government. This might involve making the South Vietnamese province and district administrations more responsive to the needs of their people, but it was an important distinction. As one PSA with two-and-a-half years of experience explained: "Your primary purpose in going overseas is the interest of the United States government. It is not the interest of Vietnamthis is our foreign policy that we are implementing." ${ }^{\prime 8}$ One holdover from the era of the Tigers was openly contemptuous of what he regarded as a "pathetic reliance on the belief that good works like fertilizer and improved rice seed are

65. Debrief No. 10668, p. 4.

66. Debrief No. 24687, p. 18, in Box 98, GP, HIA.

67. Debrief No. 11679, p. 6, in Box 94, GP, HIA; and Debrief No. 27682, p. 7, in Box 100, GP, HIA. 68. Debrief No. 126712, p. 2, in Box 99, GP, HIA. 
an end in themselves without regard to the political implications these things involve." ${ }^{69}$

For advisers from this school of thought, helping the GVN to help its own people was a means to the end of strengthening the Saigon regime in pursuit of U.S. war aims. Only when the GVN had something to offer its population could it hope to win their allegiance in the battle with the NLF. One ex-military adviser explained how he viewed his task:

We should sort of complete the circuit between some form of Vietnamese government and the people it serves as well as governs. Until we provide some evidence that the government's concerned about its constituents, I think we'll just have an open circuit. So we're trying to plug this in and make it a flow of information, a flow of loyalty. ${ }^{70}$

This view coexisted in the adviser's mind with the more developmentalist notion that the United States should help South Vietnam "raise its sights" so that it could survive economically "in today's world." ment goals mixed easily because helping the GVN to respond to the social, economic, and political needs of its citizens also served the strategic goal of fortifying the GVN.

Latent or explicit racism, as well as assumptions about Vietnamese society and culture, affected how advisers viewed rural South Vietnam and their role as agents of change within it. As has frequently been the case in U.S. citizens' encounters with foreign peoples, race acted as a double-edged sword: it could act as a marker that a foreign people was waiting to be uplifted by being made an object of the outsiders' civilizing mission, and it could simultaneously be seen as a sign that the same people would never be capable of climbing the ladder of civilization. During training, advisers read a document titled "The Vietnamese Peasant: His Value System," which leaned heavily toward the latter view, portraying peasants as superstitious, isolated, xenophobic, and selfish. Sweeping generalizations were encouraged by statements such as the supposed fact that the peasant "likes war movies, perhaps because he can identify with them." ${ }^{\prime 2}$ This portrayal fit within the mainstream of a modernization discourse that lumped all "traditional" societies together. Still, it did present the

69. Debrief No. 15681, p. 2, in Box 97, GP, HIA.

70. Debrief No. 7666, p. 24, in Box 99, GP, HIA.

71. Ibid.

72. Attachment to memorandum by Leonard Marks to Johnson, 4 January 1966, p. 6, in Box 80, WHCF, Subject File Ex CO 312, LBJL. The inclusion of this document on the training curriculum is noted in Vietnam Area Studies OCO Training Center, n.d. 
worldview of the Vietnamese peasant as something to be worked with and manipulated through propaganda rather than revolutionized by ushering the peasant into modernity.

Although some advisers seemed to internalize this portrait of the "traditional" Vietnamese peasant, others believed that no special knowledge of Vietnamese culture or society was needed to perform their jobs, arguing, in effect, that once you had seen one farmer-whether Vietnamese or American-you had seen them all. ${ }^{73}$ One adviser took comfort by assuring himself that the Vietnamese farmer "probably wants the same thing that the farmer in Georgia or Alabama wants." 74 This comparison, which was based not on intellectual discourse but on the everyday experiences of advisers who hailed from a farming background, belied the traditional/modern distinction that lay at the heart of modernization theory. Another adviser thought it would be fruitful to consider that the Vietnamese were akin to "American Jews" rather than the "Negro or Mexican sub-cultures" because the Vietnamese were merit-oriented. ${ }^{75}$ One assistant province adviser, who was not fluent in Vietnamese, even went so far as to claim that because the United States was a "basically democratic society" without class distinctions, there was a wider gap between South Vietnamese villagers and GVN officials than there was between U.S. advisers and those same villagers. ${ }^{76}$ This assistant PSA, rather than seeing his task as bringing the "traditional" rural dwellers into the "modern" world, placed his faith in the idea that U.S. personnel and Vietnamese peasants were already basically alike.

It was certainly convenient for the advisers to believe they understood the villagers without the need for communication, given that the vast majority of the Americans could not speak Vietnamese. Still others drew more realistic conclusions and did develop a sophisticated understanding of Vietnamese rural society — or at least a healthy appreciation of the limits of their own knowledge. One U.S. Army officer, with three years of experience as a PSA by 1971, rejected easy generalizations about the Vietnamese and felt that true wisdom lay in being aware of what one did not know. "Show me a person who says he understands the Vietnamese," he commented, "and I'll show you a person who only thinks he does." ${ }^{.77}$ Despite having views on race relations in

73. Debrief No. 126712, p. 2.

74. Debrief No. 16612, p. 16.

75. Debrief No. 25672, p. 23.

76. Debrief No. 6683, p. 9.

77. Attachment to memorandum by James Turner to John Paul Vann, 26 February 1971. 
the United States, "Earl" espoused careful sensitivity to the worldview of the Vietnamese:

I haven't had any cross-cultural problems myself. I realize that the Vietnamese act and react differently than we do. If you go from Mississippi to Indiana you will find people act and react differently. I think if your idea is to go over there and help these people and you're really interested in people, you're not going to have these problems. ${ }^{78}$

Some advisers avoided the generalizations that lumped all villagers together either as simple farmers akin to their U.S. counterparts or as devious and selfish egotists; instead, they gained an appreciation of the complex social and political structures of the villages and provinces in which they worked. The most sophisticated of all realized that this complex structure often had no overlap with the official GVN power structures with which they interacted. In 1970, a deputy PSA in Phu Yen Province lamented that "there are many undercurrents and back room politics that brew within the Province that no American really knows about or understands." He considered it difficult to know what the people really thought of the GVN because all he saw was "what the Vietnamese want us to see." " Edward Lansdale, an expert on counterinsurgency and psychological warfare who served in various roles in South Vietnam from 1954 to 1968, believed that most U.S. advisers did not have a sufficient understanding of the "rather highly organized" informal political structure that existed in each district and village. U.S. personnel tended to interact with GVN officials more than anyone else, but there was often little overlap between the formal structures of GVN power and the traditional community leaders in the village. ${ }^{80}$ But gaining an understanding of the local institutions required linguistic skills and cultural sensitivity that few advisers could muster. Stereotypes and generalizations of various forms, though not necessarily based on ideas about modernization, often took the place of sophisticated understanding.

In debriefings, advisers tended to have a lot more to say about their counterparts than about the villagers. It was easy for the advisers to project their own values onto the villagers because they were unable to communicate with them. By contrast, advisers communicated extensively with their GVN counterparts and often became aware of a gaping chasm in worldviews and

78. Debrief No. 4696, p. 2.

79. Memorandum by Donald Clark to HQ, 18 December 1970, p. 13, in Folder "End of tour report," Box 101, CORDS History Files, RG472, NARA.

80. Debrief No. 25687 (Lansdale), pp. 1-4, in Box 100, GP, HIA. 
priorities. Advisers necessarily spent much of their time managing relationships with their counterparts rather than focusing on reforms. Their ability to achieve their developmental and strategic goals was proportionate to their ability to influence the province and district chiefs to whom they were accredited. A great deal of an adviser's energy was taken up in managing this relationship, and the need to do so pragmatically impaired any programmatic approach to their jobs. They could not impose their will through coercion, and, as the vignette that opened this article illustrates, they sometimes had more to fear from their counterparts than vice versa. Most advisers believed that establishing a belligerent or hectoring relationship with their counterparts would be counterproductive and instead viewed their role as more akin to acting as diplomats, lobbyists, or even con men. ${ }^{81}$

Province chiefs were by definition survivors, having risen to field-grade ranks in the ARVN by managing not to get killed or purged. Most U.S. advisers hence found their counterparts to be cautious individuals who were not easily persuaded to change their established patterns of behavior just because an enthusiastic new outsider had arrived in their orbit. U.S. advisers were often struck by what they regarded as the lethargy of Vietnamese local officials, and others complained that the chiefs knew little more about their provinces than the U.S. advisers did. The chiefs frequently could not travel around the provinces because the security situation was so bad. ${ }^{82}$ Some advisers who clashed with their counterparts feared for their lives, although such experiences were at the extreme end of the spectrum of ways that GVN officials could register their aversion to U.S. interference. A much more common tactic was simply to stonewall or ignore U.S. requests.

Given the large numbers of U.S. advisers in South Vietnam, some inevitably got sidetracked from their mission in ways that strained relations with the Vietnamese. Sexual relations were a particularly sensitive area. "Brad" felt that a sure and common way for the U.S. advisers to annoy their Vietnamese counterparts "is to speak of his women in this fashion that they are all oversexed little pots who are just laying around in their hammocks waiting for that big American to come along and satisfy their beastly desires." ${ }^{83}$ Many advisers seemed to realize they were viewed negatively by their-always maleGVN counterparts if they were known to be having a sexual relationship with a Vietnamese woman, but one mused that this was a "problem" because

81. Debrief No. 8664, p. 3, in Box 94, GP, HIA (lobbyist); Debrief No. 206612, pp. 9-10 (diplomat); and Debrief No. 7666, p. 8 (con man).

82. Debrief No. 166612, pp. 14-15, in Box 98, GP, HIA; and Debrief No. 30663, pp. 1-2.

83. Debrief No. 23666, p. 9. 
"Vietnamese women are very attractive." 84 This "problem" was often treated in ways meant to be lighthearted, such as in a CORDS newsletter that noted: "For the girl-watchers, An Giang is said to have the most beautiful women in SVN, a statement that the men of CORDS/AG would heartily agree with." 85 The same newsletter published advice on administrative procedures for U.S. personnel who wanted to marry Vietnamese women, which suggests the issue was on the mind of many CORDS advisers. ${ }^{86}$ One noteworthy aspect was that once a Vietnamese woman became the wife of a U.S. citizen, she became his "dependent" and was required to leave the country for a "safe haven" such as Bangkok, Manila, or Taipei. ${ }^{87}$ Given the access to financial security, consumer goods, and even a foreign passport that U.S. personnel could offer Vietnamese women, some viewed the "problem" of relations with them somewhat differently. One agriculturalist who served in 1967-1968 explained,

I find the Vietnamese women to be probably among the coldest and most calculating of all women in the world. . . They come out at the end of a year and a half or two years smelling like a rose, with a nice bank account in Saigon or even Switzerland and the American wonders what hit him. This happens pretty often. ${ }^{88}$

For most CORDS advisers, the key task was how to manage day-to-day relationships with their GVN counterparts, and this conundrum often forced them into compromises. Although advisers had some limited leeway to act unilaterally, they found they could achieve almost nothing without the cooperation of local officials. "This is the Vietnamese country and we're advisers," explained one American who served in 1966.

This is one of the things we have to realize-we are nothing but advisers and when we act in any capacity other than advisers we are out of our element. I think that persuasion is the word that is necessary and I think that it is very necessary to be able to persuade by being knowledgeable and know what we're doing. ${ }^{89}$

84. Debrief No. 24687, 17. See also Debrief No. 18672, pp. 2-3, in Box 98, GP, HIA.

85. CFAA newsletter, No. 8, February 1972, p. 9, in Folder "CFAA Newsletters, 1971-72," Box 45, CORDS History Files, RG472, NARA.

86. Ibid., pp. 13-17.

87. CFAA newsletter, No. 1, 24 May 1971, p. 2, in Folder "CFAA Newsletters, 1971-72," Box 45, CORDS History Files, RG472, NARA.

88. Debrief No. 24681, p. 78, in Box 100, GP, HIA.

89. Debrief No. 2667 , p. 8 , in Box 100, GP, HIA. 
Another adviser, who served in I Corps in the same year, felt that doing anything against the wishes of the province chief was unwise. "The day when we start going this way and he wants to go the other way," he believed, "our usefulness is terminated." The application of careful persuasion after gaining the chief's trust - which this adviser believed could take four or five months, more than one-third of the length of an advisory tour-was the only way to go. ${ }^{90}$ Most advisers operated circumspectly, believing that hostile relations with their counterpart would destroy their ability to operate. Guidance sent to all PSAs noted that advice should be given to the province chief "in privacy so that he will not lose face when passing it to subordinates." ${ }^{11}$ As a behindthe-scenes counsel and manipulator, advisers clearly had some power but still relied on their local partner. Even if the advisers had been inclined to act as zealous modernizers, their capacity to do so would have been almost nil. In 1970, Louis F. Janowski, an FSO who served in various advisory positions in IV Corps, stated in his end-of-tour report: "Too often good counterpart relations simply means letting your counterpart do exactly what he wants or raising minimal objects $[s i c]$ to his actions." ${ }^{92}$

Almost no adviser regarded his counterpart as a puppet who was easy to manipulate into doing what the adviser wanted. "Brad" described the handicaps the advisers faced in interacting with their counterparts on an equal basis. "In the first place," he began,

let's face it, you probably tower over the guy, you weigh twice what he does, you probably are enjoying a salary several times his, and you have all kinds of amenities that he probably does not enjoy, such as access to the PX and all the goodies therein. ${ }^{93}$

Advisers could also leave the country if they had to, whereas GVN officials could not. According to Brad, these disparities meant: "You're starting the relationship under a hell of a handicap, and it's a miracle that the guy doesn't hate your guts on sight." ${ }^{\prime 4}$ It was also extremely difficult for advisers to grasp the context in which their counterparts operated. A U.S. adviser faced with

90. Debrief No. 4668, p. 18, in Box 101, GP, HIA.

91. Memorandum from Wagonhurst to all PSAs, n.d., pp. 6-7, in Folder "End of tour report," Box 102, CORDS History Files, NARA.

92. Attachment to Lee Braddock to James Eagle, 21 October 1970, in Folder "POL 7: Visits, trip reports, 1970," Box 9, Subject Files of the Office of Vietnam Affairs (Vietnam Working Group), RG59, NARA.

93. Debrief No. 23666, pp. 8-9.

94. Ibid. 
the task of understanding the political, cultural, social and economic intricacies affecting Phu Yen's province chief in 1968 confronted the same task that a Vietnamese would have faced if parachuted into California and ordered to understand the priorities of Governor Ronald Reagan. One document, written by an experienced adviser and distributed for the edification of his PSA colleagues, listed 64 questions about the counterpart's religious affiliations, business interests, sex life, political links, and educational background-the answers to which could bear on his behavior. ${ }^{95}$ Few U.S. advisers were equipped to understand any of these factors, and the language barrier only exacerbated the problem.

One of the main issues facing CORDS advisers on a daily basis was encouraging their counterparts to focus on helping the rural population even when this did not accord with the counterparts' own interests or priorities. Because almost all provincial chiefs were ARVN officers with limited experience in understanding rural life, the PSAs could find it difficult to get them to agree on the importance of such efforts. ${ }^{96}$ By late 1971 a CORDS briefer reported that in rural South Vietnam "the center of power rests with the province chief, who is by and large an Army Colonel, does not have an M.A. in Economics or Public administration, and has been fighting a war all his life." The chief's characteristic response to being told to involve himself in civil matters, the briefer said, was "to have nothing to do with it because he would have nothing to say." "977 Vann likewise considered the GVN to be "dominated by military men who have to be coerced into performing civil functions, and it was a strange role for them to perform." 98

The district level of government was where programs were actually implemented and was the echelon at which GVN officials had most contact with villagers. Although no one knew for sure given the ravages of the war, official U.S. publications estimated that South Vietnam comprised 2,100 to 2,552 villages, which were further subdivided into some 10,000-12,000 hamlets. ${ }^{99}$ Given the enormous variety of political, economic, and social circumstances in each village, CORDS advisers could not possibly have detailed knowledge

95. Memorandum from Wagonhurst to all PSAs, n.d., p. 4;< emphasis in original.

96. Debrief No. 3681, p. 16; and Debrief No. 2667, p. 2.

97. Task force minutes, program “CDD," September 1971, p. 8, in Folder "Heilman minutes of task force meetings/Taken from Chamber's safe, folder I," Box 80, CORDS History Files, RG472, NARA. 98. Task force minutes, program “CORDS/PP\&P and Mr. John Vann,” 11 October 1971, p. 19, in Folder "Heilman minutes of task force meetings/Taken from Chamber's safe, folder I," Box 80, CORDS History Files, RG472, NARA.

99. The Vietnamese Village: Handbook for Advisors (1971), p. 6, in unmarked folder, Box 4, Charles F. Sloane Papers, HIA. 
of them all, making relations with local district chiefs of paramount importance. By focusing on ensuring that the district chief governed effectively and promoted reform, CORDS advisers could hope to influence the numerous villages in each district chiefs area. One adviser noted that "[m]any programs and other regular governmental activities will either succeed, be perverted, or fail because of the district and the far ranging influence of the district chief." 100 Yet district chiefs were commonly considered to be even less concerned than province chiefs about civil administration. ${ }^{101}$

Advisers deployed various methods of manipulation. Most tried to see their counterpart at least daily and to develop social relationships with them. By offering advisers access to the U.S. provincial organizations' technical knowledge on matters such as agriculture, as well as access to the resources that CORDS was willing to invest in local development and reform programs, advisers could become valuable to their counterparts. Yet most advisers believed they should not appear too indispensable lest they undermine the appearance of the province chief's autonomy and sovereignty within his own province. One adviser commented: "It was very difficult to work in such a manner to try to get things done and to control things while, at the same time, presenting the facade that I was not manipulating anything." ${ }^{102}$ Another described his job as akin to a lobbyist, but one who did not want to appear to be too close to the politician who was being lobbied. "Try not to give the overly [sic] impression that you are with him all the time," he advised, "because he either resents it or if he doesn't resent it, he starts looking like an American puppet." ${ }^{103}$ With factors such as these limiting the direct influence the advisers could have on a province chief, some attempted indirect means of influence, such as developing closer relationships with the province chiefs deputies. By planting ideas further down the GVN hierarchy and then endorsing those ideas when they came across the province chiefs desk, advisers could maintain a facade of noninterference. They could also send their area specialists to advise and persuade lower levels of the GVN hierarchy, including cajoling the chiefs of villages and hamlets to request help from the province chief as a way of stimulating activity without it seeming to be externally inspired. ${ }^{104}$

100. Document, "The District as an Institution," n.d., p. 1, in Folder "GVN correspondence / Camp surveys," Box 15, CORDS History Files, RG472, NARA.

101. Document with attachments, subject "Strengthening of Local Government," 3 October 1969, in Folder "Economic warfare files—local government," Box 17, CDD Records, RG472, NARA.

102. Debrief No. 30663 , p. 8.

103. Debrief No. 8664, pp. 2-3.

104. Debrief No. 8664, p. 5; Debrief No. 4668, pp. 19-20; and Debrief No. 7666, p. 14. 
However, such interventions seemed to undermine the long-term goal of fostering an independent GVN.

All of these factors limited CORDS advisers' ability to implement a U.S. agenda and instead made them captives to the will of their GVN counterparts. The extent to which advisers could "modernize" GVN rural administrationeven if they had wanted to- - had its limits. This was illustrated most clearly by the example of corruption. Although the exact scale of corruption in South Vietnam is impossible to determine, especially insofar as it was carried out in petty ways at the province level and below, it was endemic throughout the period of CORDS's existence. The rural population whose allegiance was vital to the war effort suffered under myriad forms of petty graft. Far from acting as ruthless modernizers who attempted to stamp out the practice, most advisers were unwilling to interfere, for fear of wiping away the grease that kept the wheels of provincial administration turning. A handbook for advisers noted in 1971 that corruption was the "pervasive vice" of Vietnamese administration and was not to be dealt with through "denunciations and counterdenunciations." 105 One of the generation of advisers who replaced the Tigers complained that some of his predecessors had been too "idealistic." Voicing a commonly held view, he explained that corruption was an accepted norm "in more countries of the world than not" and was not something to be "overly disturbed" by. ${ }^{106}$ "The American attitude seems to be based on the assumption that corrupt practices are part of their way of life and must be accepted," stated one long-serving official, "Frank," in 1967. "Objections are based not upon kind but degree. A certain level is permissible, but more than this calls for corrective action. I subscribe to this view myself." 107 "Frank" saw 10 percent of cash or 25 percent of construction materials as an out-of-hand level of corruption, whereas others saw 10 percent cash as acceptable. ${ }^{108}$ Such views were widespread, and advisers routinely came to overlook corruption. Many advisers drew a distinction between "necessary" corruption and abuses aimed at making individuals conspicuously wealthy. ${ }^{109}$ Vann was said to differentiate between "good corruption" and "dirty corruption." 110 This distinction underlay the words of a USAID employee who said in 1968 that corruption was a "cancer" but also "the lubricant by which everything moves." Remove the

105. The Vietnamese Village, pp. 86-87.

106. Debrief No. 56610, p. 6, in Box 100, GP, HIA.

107. Debrief No. 15681, p. 31.

108. Ibid., p. 32; and Debrief No. 6683, p. 4.

109. Debrief No. 126712, pp. 7-8.

110. Former district senior adviser stationed in Phú Yên Province, interview by author, 5 May 2015. 
lubricant, he warned, and it "would be like removing all of the grease from a machine." ${ }^{111}$ Seen this way, the adviser's role was to avoid rocking the boat too much lest it overturn.

The conditions under which U.S. advisers served in rural Vietnam were not conducive to the implementation of grand plans or reform programs. The advisers thus had to chart their own course, working with the counterparts available and in accordance with their own limited understanding of Vietnamese language, government, and society. The story of U.S. rural advisers in South Vietnam is not the story of one theory rigidly applied; rather, it is the sum total of the advisers' individual struggles. Unable to speak Vietnamese or understand local political dynamics, the advisers were outsiders to the governmental structure and society they were attempting to reform. Their lack of detailed understanding of the true power dynamics of either the GVN or Vietnamese rural society made it difficult for them to act. Furthermore, the need to work through their GVN counterparts led to compromises with the needs and preferences of the very individuals whose actions they were supposedly there to change. This was especially clear on the issue of corruption. Many advisers ultimately bowed to the needs of their counterparts and accepted the argument that it was unrealistic to expect the GVN to run both efficiently and honestly in a time of war. Even if the advisers had wished to tackle the problem, their status as lonely and confused outsiders made them possible targets of stonewalling, obfuscation, or even a gun barrel to the back of the head.

\section{Conclusion}

The U.S. rural advisory network in South Vietnam developed over time, growing from a small effort modeled after the Peace Corps into a large, bureaucratized machine that deployed dozens of civilian advisers to every province of South Vietnam under military auspices. Despite the lamentations of the Tigers, this development was inevitable given the vast U.S. military buildup in the country from 1965 onward and the strategic importance of successful nation-building in South Vietnam. The rural advisory effort underwent both qualitative and quantitative change throughout the 1960s, as the young, idealistic Tigers were replaced by more experienced individuals recruited in the United States or transferred from other agencies. The U.S. government attempted to produce, on a crash basis, a cadre of advisers with

111. Debrief No. 24681, p. 47. 
expertise on South Vietnam and the cultural and political sensitivity to be effective nation-building agents.

Yet, despite the perceived importance of the Vietnam War to U.S. national interests and the Cold War-and the establishment of the only U.S. training school dedicated to producing expertise solely on one particular country - the effort was a failure. The history of the program is a reminder that although the United States has taken a global view of its interests both during and after the Cold War, it has encountered formidable limits on its ability to understand and influence the politics even of the countries with which it is most intensely concerned.

By demonstrating how the rural advisory program evolved over the course of the "Decade of Development"-often in response to conflicts within the development community, such as between the Tigers and the old guard of USAID - this article suggests the value of moving beyond a focus on one particular ideological tendency, such as modernization, and instead taking a detailed look at how Cold War development interventions were experienced from the ground up. Doing so can help achieve more nuanced understandings of the history of key U.S. nation-building efforts during the Cold War. Only by looking at the varied experiences of the many thousands of individual U.S. rural government advisers in South Vietnam can we understand the reality of how the U.S. nation-building effort there "actually operated." ${ }^{112}$ Examining how the advisers struggled against their own powerlessness to understand or influence their surroundings - often with nothing more than the can-do attitude that had been encapsulated in Fraleigh's rallying cry of "You can do it, Tiger!"-is more pertinent than an analysis of ideological discourse in the metropole to understanding the reality of the nation-building effort.

The emphasis placed here on the heterogeneity of the views and experiences of nation-builders is especially appropriate in the case of the Vietnam War, where-as in so many other aspects of the conflict-U.S. involvement was distinguished by its sheer scale. As the new source base tapped for this article demonstrates, the average U.S. adviser involved in the effort was not a doctrinaire proponent of modernization theory and did not have the training and opportunity to develop the sophisticated understanding of South Vietnam sported by individuals such as Lansdale or Vann, who have occupied an outsized position in the literature to date. ${ }^{113}$ Instead, advisers brought to their

112. Ekbladh, Great American Mission, p. 11.

113. On Lansdale and Vann, see Neil Sheehan, A Bright Shining Lie: John Paul Vann and America in Vietnam (New York: Vintage, 1989); Cecil B. Currey, Edward Lansdale: The Unquiet American (New York: Houghton Mifflin, 1989); and Jonathan Nashel, Edward Lansdale's Cold War (Amherst, MA: University of Massachusetts Press, 2005). 
role the array of preconceptions, temperaments, and aptitudes that might be expected of any large group of individuals. Focusing on the experiences of this "average" adviser suggests the value of looking at policy implementation at the micro level to see how the ideas and imperatives that shape U.S. foreign policy actually play out in practice. The micro level of interaction between individual U.S. advisers and their foreign counterparts - the level, that is, at which U.S. foreign policy meets U.S. foreign relations - is where the most interesting stories are often to be found. 